DOI: $10.33766 / 2524-0323.90 .26-39$

УДК 352.07

Н. В. Камінська,

доктор юридичних наук, професор,

професор кафедри конституційного права

та прав людини

Національної академії внутрішніх справ

(м. Київ, Україна)

e-mail: na-pro@ukr.net

iD https:/ / orcid.org/0000-0002-7727-4056

М. П. Гусяк,

аспірантка кафедри теорії держави та права

Національної академії внутрішніх справ

(м. Київ, Україна)

e-mail: gmp17@ukr.net

iD https://orcid.org/0000-0001-9262-8054

\title{
СТАТУТНІ ДЖЕРЕЛА В ПРАВОВИХ СИСТЕМАХ ВЕЛИКОБРИТАНІЇ ТА США
}

У статті здійснено грунтовне комплексне загальнотеоретичне вивчення статутних джерел у правових системах Великобританії та США, які із судовими прецедентами становлять основу англо-американської правової сім ї. В англійському праві традиційним є вузький підхід до розуміння статутів і статутного права як сукупності парламентських актів. Водночас статутне законодавство, згідно із широким підходом, поділяється на первинні (акти парламенту Великобританії, парламенту Шотландії, парламенту Уельсу та Асамблеї Північної Ірландії, законодавчі акти про церкву тощо) та вторинні акти (статутні інструменти, статутні правила, церковні інструменти тощо).

Для США характерна тенденщія збілышення масиву та ролі статутного законодавства, існує писана федеральна Конституція; ієрархія нормативних актів, яка засновується на найвищому авторитеті Основного закону; систематизація законодавства, яка полягає в значній кількості кодифікованих актів; поділ права на матеріальне та процесуальне, публічне та приватне; перевага федеральних статутних актів над судовими прецедентами та конституційний судовий контроль статутів.

Ключові слова: джерела права, статут; статутне законодавство, статутна правотворчість, правова система Великобританії, правова система США, англо-американська правова сім'я.

Постановка проблеми. Протягом останніх десятиліть відчутний взаємовплив і взаємодія національних правових систем, різних правових сімей. На наш погляд, активно це позначається на становленні й розвитку деяких правових інститутів, галузей права і джерел права. Проте, усе ж таки існують значні відмінності у визначенні основних і допоміжних джерел права романо-германської та англо-американської, а також інших правових сімей, джерел міжнародного права й національного права.

Водночас в умовах стрімкого розвитку законодавчої бази України спостерігаємо появу таких джерел права, як статути в різних галузях права й законодавства. Ідеться, наприклад, про статути політичних партій і громадських об'єднань, релігійних організацій, непідприємницьких товариств, територіальних громад і асоціацій органів місцевого самоврядування та їх добровільних об'єднань, організацій, які здійснюють

(C) Камінська Н. В.,

Гусяк М. П., 2020 
професійне самоврядування, неурядових організацій, міжнародних організацій, як міжнародних договорів України, згода на обов'язковість яких надана Верховною Радою України. Це джерела публічного й приватного права. Однак грунтовно їх соціально-правова природа не вивчена й не з'ясовано, чи деякі з цих джерел запозичені 3 інших правових систем, чи це історично сформовані вітчизняні джерела. Статути наявні в наднаціональному й міжнародному праві.

Аналіз останніх досліджень та публікацій. Проблематика статутів і статутної правотворчості рідко розглядається в окремих наукових роботах, на відміну від загальнотеоретичних і порівняльно-правових праць про джерела права. У даному контексті слід виокремити наукові здобутки вітчизняних і зарубіжних учених, зокрема М. Баймуратова, І. Біласа, Ю. Бисаги, С. Бобровнік, В. Забігайла, М. Кельмана, А. Кулька, О. Лисенко, О. Мережка, В. Нестеровича, Н. Пархоменко, Р. Петрова, Н. Пронюк, О. Скакун, Р. Тополевського, О. Фатхутдінової, К. Смирнової, О. Шпакович та ін.

Формулювання цілей. Метою даної статті є грунтовне комплексне загальнотеоретичне вивчення статутних джерел у правових системах Великобританії та США. Задля їі досягнення потрібно вирішити наступні завдання: 1) з'ясувати правову природу та особливості американської й англійської правових систем, зокрема стосовно ïx джерел права; 2) розкрити підходи до класифікації статутних джерел та принщипи статутного права; 3) виокремити спільні та відмінні риси статутів як джерел права в американському та англійському праві, їх взаємовплив.

Виклад основного матеріалу. Системи права у Великобританії та США представляють англо-саксонську правову сім'ю, яка засновується на складній взаємодії загального права (англ. Common Law), статутного права (англ. Statutory Law) та казуальному типі юридичної свідомості. Як відомо, формування англо-саксонського права припадає на період нормандського завоювання в Х ст., коли почалося формування централізованої судової системи. Рішення від імені Корони роз'їзних судів починають застосовуватися в аналогічних справах іншими судовими інстанщіями, таким чином формується прецедентне право, яке стає загальним для всієї Англії. Таке загальне право є основою англо-саксонського права.

Виникнення статутного права традищійно пов'язують із ХІІІ століттям, коли були прийняті перші статути - Мертонський статут (1235р.), Вестмінстерський статут (1275 р.). Однак, якщо розглядати статутне право як сукупність королівських актів (ордонанси, асизи, хартії, статути) та законів парламенту (статути, біллі тощо), то його витоки можна знайти ще в XI ст.

Так у 1100 р. Генріх І видав Хартію вольностей (англ. Charter of Liberties), якою затвердив свободу церкви, тобто відмовився від продажу духовних посад і від доходів із вакантних кафедр. Заборонив зловживання феодальними правами, які були, за звичаями, у його попередників (Вільгелма Завойовника і Вільельма II Рудого); барони повинні були відмовитися від тих же зловживань феодальними правами відносно власних васалів. Особливі права Генріхом I були надані місту Лондону щодо надання городянам на відкуп графства Мідлљсекс: право обирати 3-поміж себе шерифа та юстіщіарія для вирішення спорів [1]. Указана Хартія, яку їі ще називають Коронаційною хартією, мала ключове значення для розвитку статутного права як протилежності загальному праву, з огляду на наступне. По-перше, Генріх формально пов' язав 
себе із законами, створивши підгрунтя для королівського законодавства та верховенства права. По-друге, 14 пунктів цієї Хартії послужили основою та зразком для Великої хартії вольностей 1215 року. 3 цього часу саме хартії стають частою формою правових джерел. За часів Генріха II суттєво збілышується кількість законодавчих актів у різних їх формах. Так стародавня й урочиста хартія замінюється на асизи короля. Наприклад, Велика Асиза та Кларендонська Асиза 1166 р. (англ. Assize of Clarendon), які за своєю суттю були інструкціями для королівських роз'їзних суддів, але стали основою судової реформи Генріха II.

Текст Великої Асизи до наших днів не зберігся; про ії зміст та важливе значення стало відомо лише завдяки трактату XII ст. «De Legibus Angliae» юриста Гленвіля. Biдомо, що Велика Асиза вводила нову форму судового процесу в справах про вільне тримання землі. Поряд із судовим поєдинком допускалося розслідування через присяжних, яке раніше застосовувалося в королівських судах за позовами, що зачіпають інтереси корони або ї̈ безпосередніх васалів. Велика Асиза дозволяла вільному власникові, земельні права якого оскаржувалися, вести свою справу за допомогою розслідування через присяжних. Було створено умови для його поступового витіснення, оскільки кожен, хто міг купити відповідний королівський наказ, прагнув вдатися до нової процедури. 3 іншого боку, придбання однієї зі сторін наказу про початок процесу по Великій Асизі автоматично тягло за собою припинення справи в сеньйоральному суді й перенесення його в королівський суд [2].

Кларендонська Асиза, прийнята 1166 р., започатковувала нововведення у сфері кримінального процесу, зокрема, не скасовуючи «божого суду», значно обмежувала сферу його застосування, передавала всі кримінальні справи, порушені за показаннями обвинувальних присяжних, до компетенщії королівського суду, а право на майно засуджених злочинщів - короні [2]. Особливістю цього документу є фактичне проголошення принщипу рівності всіх (вільних, вілланів) перед кримінальним королівським судом, що для феодального суспільства того часу було достатньо прогресивним.

Виняткове місце у розвитку англійського конституційного та цивільного писаного права посідає Велика хартія вольностей, яка була надана королем Іоанном Безземельним 1215 р. (лат. Magna Charta libertatum). Це результат протистояння баронів із королем, у якому король вимушений був піти на поступки та надав вольності феодалам і всім вільним людям. Ії текст написаний латиною, а кожна 363 статей присвячена регулюванню певної сфери (права церкви, привілеї феодалів, право баронів на повстання проти короля, податкові правила, адміністративний і судовий порядок, гарантування особистої свободи та інше). Король зобов' язувався дотримуватися всіх наданих вольностей, в іншому випадку барони мали право на повстання, а феодали повинні були дотримуватися цих же вольностей щодо своїх людей (васалів) [1]. Крім того, передбачалося створення ради з 25 баронів для контролю за дотриманням Хартії, у першу чергу, самим королем. Закріплювалися основи інституту особистої недоторканності вільних людей, а саме: ніхто не міг бути позбавлений волі, власності та захисту закону без суду і встановленої процедури; а також затверджувалися привілеі для міста Лондона, порядок перетину кордону Англії тощо. Велика хартія вольностей є пам'яткою англійського середньовічного права та найстарішим конституційним актом, який включений до складу некодифікованої Конституції Великобританії. 
На початку XIII ст., ще до створення парламенту, набувають поширення акти короля у формі статутів. Одним із перших вважається Мертонський статут. Умови статуту були погоджені в Мертоні між Генріхом III і баронами Англії в 1235 р. Це був ще один закон як результат боротьби між баронами й королем, щоб обмежити права останнього [3, с. 87].

Мертонський статут включає 11 статей, регулює відносини між сеньйорами $\mathrm{i}$ спадкоємцями їхніх васалів, а також процедуру деяких видів судових розглядів, що доповнюють і розвивають відповідні положення Великої хартії вольностей. Найбільше значення має ст. 4 Статуту, яка дозволяла лордам «покращувати» (огороджувати) общинні пустки, ліси й пасовища. Хоча статут наказує, що таке «покращення» може бути тільки за умови, коли ленники лорда мають стільки пасовищ, скільки належить при їх триманні землі, і надає потерпілим можливість захищати свої права по асизі про нове захоплення, однак це застереження стосувалося тільки вільних власників лорда - лицарів і фригольдерів - і не охоплювало прав кріпаків - вілланів (у статуті про них не згадується). Ці положення фактично були законодавчою санкцією, з якої почалося захоплення феодалами общинних земель [4].

У середині правління Генріха III революційна група баронів заснувала спеціальний законодавчий орган, результатом чого стали положення Вестмінстерських провізій (1259р.), а коли нарешті революція завершилася, більшість положень Вестмінстерських провізій було знову введено в дію в більш регулярній формі у Великому Статуті Мальборо (1267 р.), який $є$ найстарішою чинною частиною статутного права Великобританії. Цей статут, прийнятий англійським парламентом 1267 р., складається 329 статей (капітул), чотири з яких $(1,4,15,23$ стаття) досі зберігають свою юридичну силу та називаються законами (Закон про відходи 1267 р., Закон про завдання шкоди 1267 р.). Чинний Закон про відходи 1267 р. включає положення 23-ї статті Великого статуту Мальборо про заборону забруднення та засмічення орендованої землі. Закон про завдання шкоди 1267 р. охоплює статті 1, 4, 15 Великого статуту Мальборо. Передусім проголошено незаконність отримання компенсацій за завдані збитки, крім як через суд, незалежно від стану або майна, встановлено штраф за позасудові спроби отримати відшшкодування; ст. 4 забороняе приймати відшшодування за межами округу боржника й карає за таку поведінку штрафом); ст. 15 оголошує незаконним отримання відшккодування особою на ії землі, дорогах короля або загальних вулицях [5].

3 приходом на престол короля Едуарда I (1274 р.) та утвердженням парламенту розпочинається новий етап розвитку англійського статутного права, що в той період складається переважно зі статутів, які пропонувалися королем та погоджувалися парламентом. Статути Едуарда I здійснили настільки великий вплив на середньовічне право, що відтоді короля стали називати англійським Юстініаном. Цивільне законодавство Едуарда I, яким були внесені поправки в неписане загальне право, століттями залишалося базовим законом. Його доповнили ряд спеціалізованих законів, які були прийняті для розв'язання тимчасових проблем. Чотири статути Едуарда I заслуговують особливої уваги.

Перший Вестмінстерський статут 1275 р. складався 351 статті, які були спрямовані проти: - імунітетних прав та судів крупних феодалів; - гарантування свободи ре- 
алізації виборчого права; - вдосконалення кримінального процесу; - припинення вимагання та інших зловживань королівських чиновників у центрі й на місцях (шерифів, суддів тощо; заборона par beau pleyder) [6].

Статут Глостера 1278 р. обмежив юрисдикцію місцевих судів і розширив сферу дії для відшкодування збитків. Статутом також проголошено про перевірку імунітетних привілеїв усіх англійських баронів у судовому порядку. У другому Вестмінстерському статуті 1285 р. були передбачені чотири основні зміни: статут 1) підтвердив наявність маєтку на землі, що часто пов'язано зі збереженням почесних звань; 2) зробив землю активом для цілей виплати боргу за рішенням суду; 3) лібералізував звернення до судів вищої інстанщії; 4) поліпшив закон про управління активами в разі смерті власника.

Статут 1290 р., на який зазвичай посилаються, як Quia emptores terrarum («тому що продавці земель»), заборонив надання нових феодальних прав, крім як Короною, і дозволив усім вільним людям, які тримають землю, продавати права на їі одержання за умови, якщо новий власник буде тримати цю землю від головного лорда й за ті ж служби і звичайні повинності, як і колишній власник.

Аналіз змісту та умов прийняття писаних джерел в Англії 3 Х до ХІІІ ст. дозволяє виділити щонайменше два перших етапи розвитку англійського статутного права, 3 огляду на час заснування парламенту 1265 року:

- 1066 - 1265 рр., законодавцями писаного права були королі, які: видавали ордонанси, асизи, грамоти, статути та хартії. Поступово асизи та хартії еволюціонують у форму статуту, який також проголошувався від імені короля та іменувався за назвою того місця, де приймався та проголошувався;

- 1265 - 1327 рр., коли після заснування англійського парламенту статути, як основна форма законодавчих актів, видавалися від імені короля i, очевидно, були ініщійовані ним або його найближчими радниками. На той період ще не було необхідного зв'язку між законодавством і парламентом. У 1327 р. палата общин отримала право законодавчої ініціативи й готувалися проекти статутів, які затверджувалися лордами та королем. Так статутні джерела почали перетворюватися на статути (y ïx сучасному розумінні), тобто парламентські акти, підписані королем.

Варто зазначити, що статути, видані до 1285 р., іноді розглядаються як загальне право, а не статутне, оскільки ці закони, на думку прихильників цієї точки зору, повторюють існуюче право або дають йому білыш детальний вираз. Як аргумент, зазначається, що такі акти містили пояснення певного закону, але не створювали абсолютно нового закону. Крім того, судді не завжди строго дотримувалися формулювань статуту, але намагалися тлумачити його як частину загального права 3 даного питання. До виникнення палати общин також було складно відрізнити акти парламенту від рішень або постанов королівської ради, тобто виконавчої влади. Деякі закони були прийняті, але так і не вступили в силу, а інші просто ігнорувалися. Навіть більше, уже в XIV ст. королівська Рада, яка іноді діяла через канцелярію, могла диктувати нові засоби правового захисту, такі як конкретна дія в справі, і застосовувати існуючі засоби правового захисту, такі як захист прав власності.

Водночас інші вчені розглядають окремі положення загального права як такі, що в первинному вигляді були закріплені в писаних законах, тобто в т. зв. старих ста- 
mутах. Віднесення подібних норм до загального права зумовлено тим, що їх першоджерела не збереглися [7, с. 43]. Такі стародавні акти розглядаються в межах двох періодів становлення статутного права Англії.

У XIV ст. парламентське законодавство в Англії стає все більш загальним. Король використовує парламент не тільки для того щоб наділити владою свої власні укази, але й для того щоб парламент просто ратифікував рішення, які були прийняті Радою. У міру того як палата громад стає все впливовішою в політичному плані, вона висловлює значно більше невдоволення таким порядком прийняття законів. Як наслідок, 1415 року прийнято постанову, за якою жоден закон не міг прийматися без згоди громад, до поданих ними петищій не можна було робити будь-яких доповнень або урізання, а слід лише або приймати їх цілком, або зовсім відхиляти. 3 тих пір подані громадами петиції чи клопотання перетворилися в Біллі, тобто законопроекти, пропоновані громадами на затвердження урядовій владі [1]. У цей період встановлюється дві форми законодавчих актів: статути - закони, що приймаються парламентом; укази короля (хартії, рити) - акти, у яких містилися розпорядження короля щодо застосування чинного закону.

Отже, у XV ст. зароджується нова система парламентської нормотворчості, яка передбачала чітке розділення законодавчої влади парламенту та виконавчої влади короля. Вона полягала в підготовці законопроекту, що містив точну форму слів, яку пропонувалося прийняти. На цьому етапі парламент діяв як законодавчий орган і стало звичайною практикою писати статути англійською мовою, а не французькою, як у XIV ст., або на латині в XIII ст.

За часів Тюдорів виразно прослідкковується сучасна парламентська процедура, система трьох читань тощо. За 38 років правління Генріха VIII було видано масив статутів, рівнозначно сукупному обсягу законодавства попередніх двох із половиною століть. Так, за ініціативою короля Генріха VII з династії Тюдорів, 1539 року парламент прийняв Статут про Прокламації, який наділяв короля законодавчою владою через проголошення прокламацій, що встановлювали чіткі правила регулювання, особливо з економічних питань, і надали королівські хартії (пожалувати певні права) торговельним компаніям.

Статут прокламацій був скасований у наступному правлінні й ніколи не відроджувався, а 1610 року, за правління Джеймса I, протест суддів встановив сучасну англійську доктрину, що королівські проголошення не мають сили закону, вони служать для привернення уваги громадськості до закону, не покладаючи юридичного обов'язку, не встановленого Актом парламенту [9].

У тюдорівський період парламент приймав закони політичного характеру, такі як закони, що забезпечували панування короля над новоствореною Англіканською церквою. Статути не тільки проголошувались, як у середні віки, але тепер опубліковувалися в пресі. Законодавство стало білыш детальним і сучасним. Статути також регулювали імпорт та експорт, перевезення коштів, банкрутство, сільське господарство, комерційні справи і визначали недобросовісну конкуренцію. Статут монополій 1623 р. підтвердив, що монополії суперечать загальному праву, але зробив виняток для патентоспроможних винаходів, а статут 1601 р. став основою привілеїв, якими користуються благодійні фонди. Крім того, серія законів, прийнята в кінщі 16 ст., усунула нехтування проблемою бідності, яка була викликана розпуском монастирів. 
Під час Співдружності (1649-1660) розроблено низку проектів законів у сфері реформування кримінального та цивільного процесу: реформи включали надання правової допомоги ув' язненим, модернізацію земельної та правової процедури й запровадження цивільних шююбів.

Одним із найважливіших актів в історії англійського статутного права став Білль про права, прийнятий англійським Конвентом 1689 р. унаслідок закінчення революції 1688-1689 рр. Він. юридично закріпив встановлення в Англії конституційної монархії і на сьогодні є одним із чинних конституційних актів Великобританії. Цей акт закріпив порядок престолонаслідування із застереженням; ним перераховано «стародавні права і вольності» (королю заборонено без згоди парламенту припиняти дію законів, стягувати податки, набирати й утримувати постійну армію в мирний час, засновувати комісії для ревізії Англіканської церкви, вимагати надмірних судових застав, застосовувати надмірні штрафи та жорстокі покарання, реалізовувати конфісковане майно до винесення вироку; підтверджено права всіх підданих на петищії королю, вільні вибори парламенту і розгляд своїх справ у суді присяжних; протестантів - на володіння зброєю, депутатів - на вільні дебати) [9].

У 19 ст. прийнято закони, які кодифікували частину кримінального права, що стосується окремих злочинів, крім убивства. Шляхом прийняття статутів були кодифіковані положення щодо регулювання заповітів, права власності, деліктної відповідальності, трудових відносин тощо. Отже, сучасне статутне право у Великобританії $є$ фактичним віддзеркаленням загального права, тобто тих правил і норм, які вже були застосовані на практищі та деталізовані/підтверджені судами. 3 іншого боку, норми зі статутів також є предметом судового розгляду й джерелом нових судових прецедентів. Така взаємодія загального та статутного права забезпечує еволюцію англійської правової системи через постійне правозастосування.

На наш погляд, під статутним правом можна розуміти сукупність статутів (законів), що прийняті парламентом в установленому порядку, норми яких обов' язкові до виконання. Такий підхід є вузьким, оскільки включає до статутного права лише акти парламенту, але саме він вважається традищійним.

У юридичному словнику Блека статутне право визначається як головна частина права, створювана законодавчими органами на противагу звичаєвому і прецедентному праву, а також актам, прийнятим адміністративними органами [10]. Згідно із широким підходом до розуміння статутного права, його основу складають як акти парламенту, так і акти, прийняті внаслідок делегування законодавчих повноважень парламенту іншим суб'єктам (уряду, міністерствам, королеві). Крім того, представлений вище аналіз розвитку англійського статутного права дозволяє віднести до статутного права й писані акти, які були прийняті до створення англійського парламенту (так звані «старі статути» - хартії, асизи, статути королів).

Структуру англійського статутного права можна визначити через протиставлення один одному двох складових англійської правової системи: прецедентне право статутному праву або, з огляду на традищійний поділ правових джерел, на неписані (лат. Lex non Scripta) та писані акти (лат. Lex Scripta). У цьому контексті статутне право включає таке: статути (закони) парламенту, «делеговане законодавство», «старі статути» та автономне законодавство - акти місцевих органів влади, певних установ та організацій (Англіканської церкви, компаній, профспілок та ін.). 
Причому, незалежно від обраного підходу до розуміння статутного права, очевидно, що його основу становлять закони парламенту (статути).

Законодавчі акти (статути) британського парламенту можуть бути класифіковані за різними критеріями.

1. За колом осіб, на яких вони поширюються, статути поділяються на публічні та приватні. Публічні статути поширюються на невизначене коло осіб і діють на території Великобританії, адресовані всьому народу. Дія приватних статутів поширюється на окремих осіб чи їхні групи та окремі території держави.

2. За рівнем юридичної сили можна виділити конституційні та звичайні статути. Віднесення деяких актів до складу Конституції Великобританії дозволяє говорити про їх конституційну природу. Вичерпного переліку конституційних актів у Великобританії немає, але традищійно до них належать такі: Велика Хартія Вольностей 1215 р., Habeas corpus act 1679 р., Білль про права 1689 р., Акт про престолонаслідування 1701 р, Унія з Шотландією 1707 р., Унія з Ірландією 1801 р., Акти судової реформи 1873-1875 рр., Акти про парламент 1911 р. зі змінами, внесеними актом 1949 р., Акт про судове переслідування Корони 1947 р., Акт про громадянство 1981 р., Акт про права людини 1998 р., Акт про місцеве самоврядування 2000 р. та інші.

3. За способом систематизації статути поділяються на консолідовані та кодифіковані. Прикладом сучасної консолідації є Закон про профспілки та трудові відносини 1992 р., який об'єднав білыше 10 законів, що повністю або частково регулювали діяльність профспілок. Такі акти підлягають білыш суворому контролю при їх прийнятті в парламенті [12, с. 160 -161].

4. За специфікою мети прийняття статути можна поділити на процедурні, фрінансові та тлумачні. Процедурні статути - це акти, які уточнюють загальне право, встановлюють нові положення (enabling acts), скасовують певні положення загального права (disabling acts). Їх називають актами реформи права. Фінансові статути встановлюють податки, містять пропозиції зміни до бюджету, затверджують порядок щорічних надходжень до державної скарбнищі. Тлумачні статути містять визначення понять, які використовуються в інших статутах.

3 огляду на принципи парламентського суверенітету та верховенства статутів, логічно було б припустити наявність пріоритету статутів над прецедентами, але своєрідність англійського права в цьому й полягає, що на практищі вказаний висновок не підтверджується, тому статут не можна розглядами як джерело, яке руйнує чи нівелює систему прецедентів, а навпаки, він $є$ доповненням цієї системи, що удосконалює iii $[13$, c. 515-516].

Своєю чергою, у Великобританії поширеним є поділ законодавства (писаних джерел, згідно з широким підходом - статутного права) на первинні та вторинні акти. Вищенаведена класифікація статутів здійснена в межах вузького підходу до їх розуміння, тобто лише як актів парламенту, але інтерес викликає й класифікація статутних джерел крізь призму широкого підходу.

Перші стосуються основних законів, прийнятих законодавчими органами Великобританії, включаючи акти, прийняті історичними парламентами, інші - первинні закони - для Північної Ірландії й Церкви Англії (англ. Church of England measures). Особливість статутного права Великобританії обумовлено також і можливістю внесення до Парламенту так званих «приватних законопроектів, які «подаються у формі 
петищії (private bills) з питань, що зачіпають інтереси певної групи населення чи певної території» [14, с. 25].

Вторинні акти («підзаконне законодавство») - це делеговане законодавство, створене особою або органом, наділеним повноваженнями, делегування яких передбачене в первинному законодавстві. Як правило, повноваження щодо їх розробки надані міністрам, Короні або державним органам. Наприклад, Управління зв' язку наділене такими повноваженнями відповідно до Закону про зв'язок 2003 р. Основними видами підзаконних актів є статутні інструменти: статутні правила та розпорядження, церковні інструменти. Статутні інструменти, як правило, бувають у формі наказів, інструкцій та правил, однак яких-небудь вимог щодо форми та назви статутного інструменту немає. Вони фактично мають таку ж юридичну силу, що й закони парламенту, відповідно до яких і на виконання яких вони приймаються. Статут і статутний інструмент читаються як один закон: акт діє до того часу, доки діє статут. Скасування статуту призводить до втрати чинності всіх пов' язаних із ним актів.

Шотландські Статутні інструменти видаються з 1999 р., відповідно до положень Актів шотландського парламенту. У Північній Ірландії видаються еквівалентні Статутні правила; Валлійські Статутні інструменти є статутними документами, що відносяться конкретно до Уельсу. До підзаконних актів також належать акти місцевих органів влади та публічних корпоращій (транспортні компанії, комунальні служби). Їх дія обмежується конкретним місцевим районом або діяльністю конкретного державного органу.

Англійський підхід до поняття, класифікації та місця статутних джерел у правовій системі схожий із розумінням статутного права в США, що зумовлено історичним розвитком американської правової системи та їі приналежністю до англо-саксонської правової сім'ї. Основні етапи становлення американської правової системи в цілому та статутного права зокрема зводяться до наступного.

Перші англійські поселенщі в Північній Америщі принесли з собою лише елементарні поняття закону. Колоніальні хартії наділяли їх традищійними правовими привілеями англійських громадян, такими як Habeas corpus і право на суд присяжних. Проте, було мало суддів, юристів та збірників прецедентів, тому рішення англійських судів не швидко до них доходили. Кожна колонія прийняла власні закони, а губернатори або законодавчі органи діяли, як суди. Англійські закони, прийняті після дати розселення, не застосовувалися автоматично в колоніях, і навіть законодавство про переселення підлягало адаптації. Англійські судові справи не були обов'язковими прецедентами. Кілька американських колоній ввели основні правові кодекси, такі як Массачусетс 1648 р. і Пенсильванія 1682 р.

У 1701 р. на Род-Айленді був прийнятий закон про застосування англійського права в повному обсязі з урахуванням місцевого законодавства, і те саме відбулося в Північній і Південній Каролінах у 1712 і 1715 рр. На практиці інші колонії також застосовували загальне право з місцевими варіаціями. У період, що передував американській революції (1775-1783), багато правових спорів велося на принципах загального права, і половина підписантів Декларації незалежності були юристами, тому в Конституції США використовуються традищійні англійські юридичні терміни. 
Після американської революції відродилося прагнення замінити закон, прийнятий суддями, на народне законодавство. У середині XIX ст. реформатор Девід Дадлі Філд керував розробкою кількох кодексів та проводив кампанію за систематичну й раціональну кодифікацію законодавства США. За винятком цивільного кодексу, який сприймався штатами, кодекси Філда не знайшли широкого застосування в законодавчих органах штатів. Цивільний кодекс Філда був прийнятий п'ятьма штатами, включаючи Каліфорнію та Нью-Йорк, але цивільний кодекс став просто ще одним законом. Він застосовувався крізь призму існуючого прецедентного права й доповнювався ним, а не сприймався як повний набір чітких правил, як це було з кодексами континентального права. Сдиним американським штатом, який має кодекс у сенсі цивільного (континентального) права, є Луїзіана. Ії правова система становить гібрид елементів цивільного й загального права.

Незважаючи на провал руху кодифікації, законодавство США ставало все білыш статутним, тому до кінщя XX ст. обсяг статутів переважав над законом, створеним суддями. Американські статутні джерела можна розглядати за аналогією з англійськими статутами, у вузькому та широкому значенні. Статутне право США поділяється на федеральне та право штатів і в широкому розумінні включає таке: Конституцію США, акти Конгресу, федеральні підзаконні акти, конституції штатів, закони штатів, акти органів виконавчої влади штатів та акти органів місцевого самоврядування.

Федеральне статутне право США являє собою здебільшого нормативні правові акти (винятком є приватні статути, оскільки вони стосуються інтересів конкретних осіб), прийняті Конгресом США у формі біллів або спільних резолюцій, і які стали після цього законами в установленому Конституцією США порядку. Відомчі нормативні акти в США видаються на виконання статутів, а президентські акти, крім статутів, можуть грунтуватися на положеннях Конституції США [15, с. 9-16]. Статутне право в США відіграє вкрай важливу роль у врегулюванні суспільних відносин, свідченням чому є досить велика роль громадськості в ініціюванні та розробці проектів нормативно-правових актів федеральними органами влади США [16].

Статутне право штатів створюється законодавчими та виконавчими органами штату, а також органами місцевого самоврядування. Судова гілка влади, яка застосовує та інтерпретує закони штату, підзаконні нормативні акти, а також місцеві постанови, має право їх і скасовувати. Визнання судом статуту неконституційним не тягне його автоматичного скасування, оскільки він повинен бути скасований наступним законом. Така процедура зумовила ситуацію, коли багато федеральних законів і законів штатів залишалися в юридичних збірниках протягом десятиліть після того, як вони були визнані неконституційними. Однак, відповідно до принципу stare decisis, жоден нижчестоящий суд не буде приводити у виконання неконституційний закон, і будь-яке рішення, у якому суд це зробить, буде скасовано Верховним судом. 3 цього випливає така особливість американського статутного права, як конституційний судовий контроль та скасування статуту судом, як його можливий наслідок. Іншою особливістю є масштабна кодифікація, що забезпечила поділ права на певні галузі та закріпила рівень юридичної сили.

Сьогодні всі штати, крім Пенсильванії, завершили процес кодифікації всього свого статутного права в юридичні кодекси. Природно, існує велика різноманітність у структурі кодексів штатів, що випливає з різноманітності статутного закону, на 
якому вони були побудовані. Нью-йоркські кодекси відомі як «закони». Каліфорнія і Техас просто називають їх «Кодексами». Інші штати використовують такі терміни, як «Кодекс [назва штату]», «переглянутий Статут, або скомпільований Статут» для своїх збірок. Каліфорнія, Нью-Йорк і Техас використовують окремі Предметні кодекси. Кодекс Меріленду станом на 2016 рік був повністю переведений із пронумерованих статей в іменовані статті. Тільки Луїзіана має п'ять предметно-спеціальних кодексів та набір перероблених статутів для всіх інших сфер.

Висновки. Статутні джерела разом із судовими прецедентами становлять основу англо-американськоїправової сім ї. Англійське статутне право бере свійпочаток із писаних актів королів (асизи, хартії, статути), перші з яких датуються XI століттям. Тільки у XVII ст., з утвердженням в Англії конституційної монархії та прийняттям Білля про права 1689 р., остаточно закріплюється принщип верховенства статутів та розмежовуються правотворчі повноваження між парламентом та виконавчою владою. В англійському праві традищійним є вузький підхід до розуміння статутів і статутного права як сукупності парламентських актів. Водночас статутне законодавство, згідно із широким підходом, поділяється на перьинні (акти парламенту Великобританії, парламенту Шотландії, парламенту Уельсу та Асамблеї Північної Ірландії, законодавчі акти про церкву тощо) та вторинні акти (статутні інструменти, статутні правила, церковні інструменти тощо).

Аналіз статутного права США свідчить про те, що тенденція віддалення американської правової системи від англійської системи права зберігається, відповідно, збільшення масиву та ролі статутного законодавства в США продовжується. Американське право вже набуло таких, невластивих для англійського права, рис: наявність писаної федеральної Конституції; ієрархія нормативних актів, яка засновується на найвищому авторитеті Основного закону; систематизація законодавства, яка полягає в значній кількості кодифікованих актів; поділ права на матеріальне та процесуальне, публічне та приватне; перевага федеральних статутних актів над судовими прецедентами та конституційний судовий контроль статутів.

\section{Використані джерела:}

1. Энщиклопедический словарь Брокгауза и Ефрона. 1890-1907. URL: https://www. booksite.ru/fulltext/bro/kga/brokefr/.

2. Хрестоматия памятников феодального государства и права стран Европы. М. Гос. изд. юр. лит. 1961.

3. Барг М. А. Исследования по истории английского феодализма в XI- XIII в. М.: Академия наук СССР, 1962. 381 с.

4. The statutes of the realm, ed. by J. Caley and W. Elliott, v. 1, L., 1810.

5. The Statute of Marlborough 1267 [Distress]. URL: http://www.legislation.gov. uk/aep/ Hen3cc1415/52/1/.

6. История государства и права средневековой Англии XIII - XV вв.: Хрестоматия / Сост., ред. А. А. Тесля. Хабаровск: Изд-во ДВГУПС, 2006. 185 с.

7. Вербова О. В. Статутное право Англии: историко правовой аспект. Устойчивость и прогрессивное развитие правовых систем в контексте интеграционных процессов: сборник научных статей /под. ред. С. Е. Чебуранова. Гродно: ГрГУ, 2017. С. $42-45$.

8. Ilbert, (1914). Mechanics of haw Making, Carpentier Lectures, Columbia University Press, pp.143-144. 
9. Кондратьев С. В. Российская историческая энциклопедия. Т. 2. М., 2015, с. 593.

10. Black's Law Dictionary with Pronunciations. 6th ed. L.: Publisher's editorial staff. St. Paul, West publ. co., 1990, p. 1412.

11. Михайлов А. Законодательство (статутное право) как источник английского права: общая характеристика. ПравоБлог. 2013. URL: https:/ / blog.pravo.ru/blog/7780.html.

12. Матинян М. А. Роль статута в английском праве. Теория и практика общественного разъития. 2009. №1. С. 184-188.

13. Теория государства и права: учебник дпя юрид. вузов и факульт./ под. ред. В. М. Корельского, В. Д. Перевалова. М. : НОРМА-ИНФРА. 1998.570 с.

14. Нестерович В. Конституційно-правові форми лобіювання у правотворчому процесі Великої Британії. Віче. 2009. № 13. С. $24-26$.

15. Ваньков А. В. Статутное право и нормативные правовые акты исполнительной ветви власти США: юридическая природа и систематизация: дис. ... канд. юрид. наук. Пермь, 2018. 168 c.

16. Нестерович В. Ф. Петиційна форма впливу громадськості на прийняття нормативно-правових актів у США. Бюлетень Міністерства юстиції Украӥни. 2014. № 3. С. 96-102.

17. Костицький М. В., Камінська Н. В., Кушакова-Костицька Н. В. Перспективи вдосконалення діяльності Конституційного Суду України в умовах сучасних суспільних трансформацій. Journal «ScienceRise: Juridical Science». 2019. №3(9). C. 4-11. doi: 10.15587/25234153.2019.180113.

18. Пронюк Н. В. Сучасне міжнародне право: навч. посіб. Київ: КНТ, 2010. 280 с.

\section{References:}

1. Enciklopedicheskij slovar Brokgauza i Efrona. 1890-1907. N. d. N. p. URL: https:/ / www. booksite.ru/ fulltext/bro/kga/ brokefr/. [in Russian].

2. Hrestomatiya pamyatnikov feodalnogo gosudarstva i prava stran Evropy. (1961) Moskva. Gos. izd. yur. lit. [in Russian].

3. Barg, M. A. (1962) Issledovaniya po istorii anglijskogo feodalizma v XI- XIII v. Moskva: Akademiya nauk SSSR. [in Russian].

4. The statutes of the realm (1810). J. Caley, \& W. Elliott (Ed.) Vol. 1, L. [in English].

5.The Statute of Marlborough 1267 [Distress]. N. d. N. p. URL: http://www.legislation.gov. uk/aep/Hen3cc1415/52/1/. [in English].

6. Istoriya gosudarstva i prava srednevekovoj Anglii XIII - XV vv.: Hrestomatiya. (2006) A. A. Teslya. Habarovsk: Izd-vo DVGUPS. [in Russian].

7. Verbova, O. V. (2017) Statutnoe pravo Anglii: istoriko pravovoj aspekt. Ustojchivost i progressivnoe razvitie pravovyh sistem $\mathrm{v}$ kontekste integracionnyh processov: sbornik nauchnyh statej. S. E. Cheburanov (Ed.). Grodno: GrGU, 42-45. [in Russian].

8. Ilbert, (1914). Mechanics of haw Making, Carpentier Lectures, Columbia University Press, rr.143-144. [in English].

9. Kondratev,S. V.(2015) Rossijskaya istoricheskaya enciklopediya. Vol.2. Moskva, 593. [in Russian].

10. Black's Law Dictionary with Pronunciations. (1990). 6th ed. L.: Publisher's editorial staff. St. Paul, West publ. so., 1412. [in English].

11. Mihajlov, A. (2013) Zakonodatelstvo (statutnoe pravo) kak istochnik anglijskogo prava: obshaya harakteristika. PravoBlog. URL: https://blog.pravo.ru/blog/7780.html. [in Russian].

12. Matinyan, M. A. (2009) Rol statuta v anglijskom prave. Teoriya i praktika obshestvennogo razvitiya - Theory and practice of social development,1, 184-188. [in Russian].

13. Teoriya gosudarstva i prava: uchebnik dlya yurid. vuzov i fakult. (1998) V. M. Korelskij, V. D. Perevalov (Eds.). Moskva: NORMA-INFRA. [in Russian]. 
14. Nesterovych, V. F. (2009) Konstytutsiyno-pravovi formy lobiyuvannya u pravotvorchomu protsesi Velykoyi Brytaniyi. Viche - Viche, 13, 24-26. [in Ukrainian].

15. Vankov, A. V. (2018). Statutnoe pravo i normativnye pravovye akty ispolnitelnoj vetvi vlasti SShA: yuridicheskaya priroda i sistematizaciya. Candidate's thesis. [in Russian].

16. Nesterovych, V. F. (2014) Petytsiyna forma vplyvu hromads' kosti na pryynyattya normatyvno-pravovykh aktiv u SShA. Byuleten' Ministerstva yustytsiyi Ukrayiny - Bulletin of the Ministry of Justice of Ukraine, 3, 96-102. [in Ukrainian].

17. Kostytskyi, M. V., Kaminska, N. V., \& Kushakova-Kostytska, N. V. (2019). Perspektyvy vdoskonalennia diialnosti Konstytutsiinoho Sudu Ukrainy v umovakh suchasnykh suspilnykh transformatsii. Journal "ScienceRise: Juridical Science", 3(9), 4-11. DOI: 10.15587/2523-4153.2019.180113 [in Ukrainian].

18. Proniuk, N. V. (2010). Suchasne mizhnarodne pravo - Modern international law. Kyiv: KNT. [in Ukrainian].

Стаття надіӥшла до редколегї 22.07.2020

Каминская Н. В. доктор юридических наук, профессор, профессор кафедры конституционного права и прав человека Национальной академии внутренних дел (г. Киев, Украина)

Гусяк М. П., аспирантка кафедры теории государства и права Национальной академии внутренних дел (г. Киев, Украина)

\section{УСТАВНЫЕ ИСТОЧНИКИ В ПРАВОВЫХ СИСТЕМАХ ВЕЛИКОБРИТАНИИ И США}

В статье осуществлено основательное комплексное общетеоретическое изучение уставных источников в правовых системах Великобритании и США, которые с судебными прецедентами составляют основу англо-американской правовой семьи. В английском праве традиционным является узкий подход к пониманию уставов и статутного права как совокупности парламентских актов. В то же время уставное законодательство, согласно широкому подходу, делится на первичные (акты парламента Великобритании, парламента Шотландии, парламента Уэльса и Ассамблеи Северной Ирландии, законодательные акты о церкви и т. д.) и вторичные акты (уставные инструменты, уставные правила, церковные инструменты и т.д.).

Для США характерна тенденция увеличения массива и роли уставного законодательства; существует писаная федеральная Конституция; иерархия нормативных актов, которая основывается на высоком авторитете Основного закона; систематизация законодательства, которая заключается в значительном количестве кодифищированных актов; разделение права на материальное и процессуальное, публичное и частное; преимущество федеральных уставных актов над судебными прецедентами и конституционный судебный контроль уставов.

Ключевые слова: источники права, устав; уставное законодательство, уставная правотворчество, правовая система Великобритании, правовая система США, англо-американская правовая семья. 


\section{Kaminska N., \\ Doctor of Law, Professor, \\ Professor of the Department \\ of Constitutional Law and Human Rights of the National Academy of Internal Affairs \\ (Kyiv, Ukraine) \\ Gusyak M., \\ Post-graduate student of National Academy \\ of Internal Affairs \\ (Kyiv, Ukraine)}

\section{STATUTORY SOURCES IN GREAT BRITAIN AND USA LEGAL SYSTEMS}

The article provides a thorough comprehensive general theoretical study of the statutory sources in the legal systems of Great Britain and the United States, which with judicial precedents form the basis of the Anglo-American legal family. In English law, a narrow approach to understanding statutes and statutory law as a set of parliamentary acts is traditional. At the same time, statutory legislation is broadly divided into primary (acts of the British Parliament, the Scottish Parliament, the Parliament of Wales and the Assembly of Northern Ireland, church legislation, etc.) and secondary acts (statutory instruments, statutory rules, ecclesiastical instruments, etc.).

The United States is characterized by a tendency to increase the array and role of statutory legislation, there is a written federal Constitution; hierarchy of regulations, which is based on the highest authority of the Basic Law; systematization of legislation, which consists of a significant number of codified acts; division of rights into substantive and procedural, public and private; the superiority of federal statutes over judicial precedents and constitutional judicial review of statutes.

Analysis of US statutory law shows that the trend of distance of the American legal system from the English legal system persists, respectively, increasing the array and role of statutory law in the United States continues. American law has already acquired the following features uncharacteristic of English law: the existence of a written federal constitution; hierarchy of regulations, which is based on the highest authority of the Basic Law; systematization of legislation, which consists in a significant number of codified acts; division of rights into substantive and procedural, public and private; the superiority of federal statutes over judicial precedents and constitutional judicial review of statutes.

Keywords: sources of law, charter; statutory law, statutory lawmaking, UK legal system, US legal system, anglo-american legal family. 